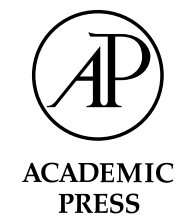

\title{
Using matK sequence data to unravel the phylogeny of Casuarinaceae
}

\author{
Dorothy A. Steane, ${ }^{\mathrm{a}, *}$ Karen L. Wilson, ${ }^{\mathrm{b}}$ and Robert S. Hill ${ }^{\mathrm{c}, \mathrm{d}}$ \\ ${ }^{a}$ School of Plant Science, University of Tasmania, Private Bag 55, Hobart, TAS 7001, Australia \\ ${ }^{\mathrm{b}}$ Royal Botanic Gardens Sydney, Mrs. Macquaries Road, Sydney, NSW 2000, Australia \\ ${ }^{\mathrm{c}}$ Centre for Evolutionary Biology and Biodiversity, South Australian Museum, North Terrace, Adelaide, SA 5000, Australia \\ ${ }^{\mathrm{d}}$ Department of Environmental Biology, University of Adelaide, Adelaide, SA 5005, Australia
}

Received 7 May 2002; revised 17 December 2002

\begin{abstract}
Casuarinaceae are a Gondwanic family with a unique combination of morphological characters not comparable to any other family. Until recently, the 96 species in the family were classified in a single genus, Casuarina s.l. A recent morphological revision of the family resulted in the splitting of Casuarina s.l. into four genera-Allocasuarina, Casuarina s.s., Ceuthostoma, and Gymnostoma. This study uses mat K sequence data from 76 species of Casuarinaceae and eight outgroup taxa to examine the phylogenetic structure within the Casuarinaceae. The study demonstrates the monophyly of the four genera and examines the relationships within the family; it tests the validity of the infra-generic subdivision of Allocasuarina; it discovers geography-based infra-generic subdivisions within Gymnostoma and Casuarina; and, finally, provides a molecular framework on which to trace the evolution of xeromorphy in the Casuarinaceae.

Crown Copyright (C) 2003 Published by Elsevier Science (USA). All rights reserved.
\end{abstract}

\section{Introduction}

The family Casuarinaceae originally contained a single genus, Casuarina L. However, over the last two decades a morphological revision of Casuarinaceae resulted in the splitting of Casuarina into four genera (Johnson and Wilson, 1989): Gymnostoma L. Johnson (18 species; one in northeastern Queensland, the rest in Malesia, the Solomons, Fiji and New Caledonia), Ceuthostoma L. Johnson (two species in Malesia, from Palawan and Borneo to New Guinea), Casuarina L. (17 species; six in Australia, the rest extending from the Bay of Bengal to Polynesia) and Allocasuarina L. Johnson (endemic to Australia; 58 species, divided among 14 sections). All of these genera grow in tropical climates, but Casuarina extends into warm temperate regions of Australia and Allocasuarina is concentrated mainly in warm to cool temperate regions (southern Australia). The splitting of Casuarina into four genera and the naming of numerous new species of Allocasuarina has received some criticism; see for example, exchanges be-

\footnotetext{
${ }^{*}$ Corresponding author. Fax: +61-3-62262698.

E-mail address: dorothy.steane@utas.edu.au (D.A. Steane).
}

tween Hwang (1990, 1991a,b, 1992), Crisp (1991) and Johnson (1991).

Casuarinaceae are a Gondwanic family. Pollen attributed to Casuarinaceae has been found in Paleocene through to Miocene deposits in South Africa (Coetzee and Muller, 1984; Coetzee and Praglowski, 1984), Argentina (Archangelsky, 1973), New Zealand (Mildenhall, 1980) and Australia (Johnson and Wilson, 1989; Macphail et al., 1994). As well as being the second most widely distributed genus of Casuarinaceae today, Gymnostoma is the oldest and most broadly distributed genus in the fossil record. Megafosssils of Gymnostoma are recorded from Paleocene sediments in New South Wales (Scriven and Hill, 1995), Eocene in South Australia, Victoria and Queensland (Christophel, 1980, 1989), O1igocene in Tasmania (Hill and MacPhail, 1983) as well as the Miocene of New Zealand (Campbell and Holden, 1984) and South America (Frenguelli, 1943). There are only a couple of records of Casuarina from the Miocene and Pliocene (Campbell and Holden, 1984; Christophel, 1989) and there is no certain fossil record of Allocasuarina until the early Pleistocene (Jordan, 1997), although some fossils currently reported as Casuarina may belong to this genus (Dilcher et al., 1990). Casuarinaceae no 
longer occur in New Zealand, South America or southern Africa.

Phylogenetic relationships among the genera of Casuarinaceae are unclear. Johnson and Wilson (1989) suggested that Gymnostoma and Ceuthostoma represent the more primitive members of the family, while Allocasuarina represents the most derived genus. The extreme morphological reduction seen in this family, as well as the unique combination of morphological traits (e.g., drooping equisetoid twigs, reduced scale-like leaves in whorls forming toothed sheaths at each node, inflorescences with alternating whorls of tooth-like bracts and reduced flowers, wind-pollination, woody 'cone'-like infructescences, winged samaras as fruits), make comparative studies of morphology difficult. Evidence from the fossil record is inconclusive. The oldest megafossils, from Late Paleocene sediments, have been assigned to an extinct species of Gymnostoma (see Scriven and Hill, 1995), with non-xeromorphic characters such as stomata in open grooves and few or no trichomes. These plants probably grew in moist environments, ideal for preservation in the fossil record. Fossils of xeromorphic plants are generally rare because the dry environmental conditions in which they exist are not conducive to the preservation of the plants in the fossil record. Xeromorphic Casuarinaceae began to appear in the megafossil record 20-30 million years ago, corresponding with the desiccation of the Australian continent. This change may represent either the adaptation of non-xeromorphic plants to the increasing aridity, or the geographic and taxonomic radiation and increase in population sizes of xeromorphic taxa that were already in existence in small patches of dry habitat, but which expanded their ranges rapidly with the onset of arid conditions.

Morphological character distributions among the genera are complex and preliminary cladistic analyses (Johnson and Wilson, unpub.) have suggested that phylogenetic and biogeographic relationships among genera may not be decipherable from morphology alone. Within Casuarinaceae xeromorphic plants were grouped together (by Poisson, 1874) as 'Cryptostomae' (species of the current genera Casuarina and Allocasuarina), as distinct from 'Gymnostomae' (Gymnostoma). As the name suggests, the stomata of the Cryptostomae (including Ceuthostoma) are concealed in deep furrows. Those of Gymnostomae are exposed in shallow furrows and are therefore more prone to water loss. While Ceuthostoma shares this xeromorphic feature with Casuarina and Allocasuarina, its general morphology resembles that of Gymnostoma (Johnson and Wilson, 1989). For this reason, the phylogenetic position of Ceuthostoma relative to the other three genera remains unresolved.

Not only are the phylogenetic relationships within Casuarinaceae unclear, but the sister group of the family also remains enigmatic, given the isolated position of the family in terms of morphological and molecular data. As stated earlier, the combination of morphological traits (see above) that characterise this family is unique, making comparative studies of morphology difficult. Manos and Steele (1997) in their molecular study of the 'higher' Hamamelids placed Casuarinaceae in a clade with Betulaceae, Myricaceae, and Ticodendraceae. Their combined analysis of $r b c \mathrm{~L}$ and $m a t \mathrm{~K}$ sequence data indicated that, of the taxa included in their study, Betulaceae was the most likely sister taxon. These data were verified in an $r b c \mathrm{~L}$ analysis of the Hamamelidae and their allies by Qiu et al. (1998).

Although Casuarinaceae have been thoroughly revised and described, phylogenetic information about the group is limited. Sogo et al. (2001) carried out a study of $r b c \mathrm{~L}$ and $m a t \mathrm{~K}$ sequences in the family; their results support the recognition of four genera, but their study was based on a limited number of species. In this study we looked at 76 species of the 96 recognised in the family. We amplified approximately $1500 \mathrm{bp}$ of sequence from the $3^{\prime}$ end of the mat $\mathrm{K}$ gene (and trnK intron; see Fig. 1) from the chloroplast genome (Hilu and Liang, 1997; Neuhaus and Link, 1987; Olmstead and Palmer, 1994), and used the data to reconstruct a more detailed phylogeny of the Casuarinaceae. This phylogenetic framework was used to to examine the evolution of xeromorphy in Casuarinaceae: did it arise just once before the divergence of Ceuthostoma, Allocasuarina, and Casuarina, or did it arise more than once, with Ceuthostoma acquiring xeromorphic characters in parallel with Casuarina and Allocasuarina?

\section{Materials and methods}

Ninety-one samples of Casuarinaceae (representing 53 species of Allocasuarina, 11 species of Casuarina, 1 species of Ceuthostoma and 11 species of Gymnostoma) and three samples of two outgroup taxa (Betula and

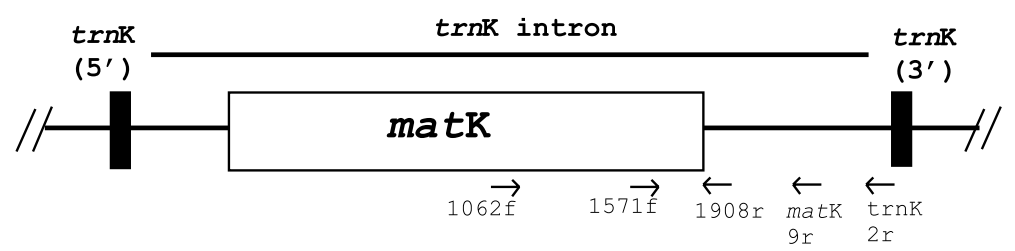

Fig. 1. Location of $m a t \mathrm{~K}$ gene within the $\operatorname{trn} \mathrm{K}$ cistron. Solid boxes represent the $5^{\prime}$ and $3^{\prime} \operatorname{trn} \mathrm{K}$ exons; the $m a t \mathrm{~K}$ gene, represented by the open box, is part of the $\operatorname{trn\mathrm {K}}$ intron. Approximate locations of the primers used in this study are indicated. 
Table 1

Casuarinaceae taxa used in the analysis of mat $\mathrm{K}$ sequence data

\begin{tabular}{|c|c|c|c|c|}
\hline Taxon & Section $^{\mathrm{a}}$ & Collection No. & GenBank & Source; locality ${ }^{\mathrm{b}}$ \\
\hline \multicolumn{5}{|l|}{ Allocasuarina } \\
\hline A. acutivalvis subsp. acutivalvis & 5. Ceropitys & P Jobson 7048 & AY191668 & Wild; Moorine Rock, WA \\
\hline A. acutivalvis subsp. prinsepiana & 5. Ceropitys & P Jobson 7123 & AY191669 & Wild; E of Buntine, WA \\
\hline A. brachystachya & 11. Cylindropitys & KLW 3191 & AY191647 & RBG Sydney; SE of Tingha, NSW \\
\hline A. campestris & 5. Ceropitys & KP3 & AY191666 & Kings Park, WA; source unknown \\
\hline A. corniculata & 11. Cylindropitys & NSW 481136 & AY191672 & RBG Annan; ex Kings Park \\
\hline A. crassa & 11. Cylindropitys & DAS 99001 & AY191644 & RTBG; Cape Pillar, Tas \\
\hline A. decaisneana & 1. Dolichopitys & KP1 & AY191677 & Kings Park, WA; source unknown \\
\hline A. decussata & 6. Allocasuarina & CBG 13301 & AY191660 & CBG; Channybeerup, WA \\
\hline A. dielsiana & 5. Ceropitys & KLW 9750 & AY191664 & RBG Annan; Murchison R, WA \\
\hline A. diminuta subsp. annectens & 11. Cylindropitys & KLW 9835 & AY191637 & Wild; SW of Corang River, NSW \\
\hline A. diminuta subsp. diminuta & 11. Cylindropitys & KLW 9759 & AY191643 & RBG Annan; Crokers Range, NSW \\
\hline A. distyla & 11. Cylindropitys & KLW 9761 & AY191638 & $\begin{array}{l}\text { RBG Annan; Glowworm Tunnel } \\
\text { road, NSW }\end{array}$ \\
\hline A. duncanii & 11. Cylindropitys & RTBG 970397 & AY191625 & RTBG; Snug Tiers, Tas \\
\hline A. emuina & 11. Cylindropitys & KLW 9767 & AY191634 & RBG Sydney; Mt Emu, Qld \\
\hline A. eriochlamys subsp. eriochlamys & 5. Ceropitys & KP5 & AY191663 & Kings Park, WA; source unknown \\
\hline A. fibrosa & 2. Oxypitys & KP6 & AY191675 & Kings Park, WA; source unknown \\
\hline A. fraseriana & 7. Amorphopitys & NSW 481139 & AY191658 & RBG Annan; Kings Park, WA \\
\hline A. glareicola & 11. Cylindropitys & KLW 9764 & AY191641 & $\begin{array}{l}\text { RBG Annan; Castlereagh area, } \\
\text { NSW }\end{array}$ \\
\hline A. globosa & 5. Ceropitys & KP4 & AY191661 & Kings Park, WA; source unknown \\
\hline A. grampiana & 11. Cylindropitys & PG Abell 451 & AY191626 & RBG Annan; Mt William, Vic. \\
\hline A. grevilleoides & 2. Oxypitys & P Jobson 7237 & AY191676 & Wild; N of Mogumber, WA \\
\hline A. gymnanthera & 11. Cylindropitys & KLW 9785 & AY191635 & Wild; NW of Denman, NSW \\
\hline A. helmsii & 5. Ceropitys & P Jobson 6948 & AY191667 & Wild; Kimba, SA \\
\hline A. huegeliana & 8. Oopitys & KLW 9763 & AY191655 & $\begin{array}{l}\text { RBG Annan ex Gordon Inlet Road, } \\
\text { WA }\end{array}$ \\
\hline A. humilis & 13. Trachypitys & KP2 & AY191619 & Kings Park, WA; source unknown \\
\hline A. inophloia & 10. Inopitys & D Blaxell 88/199 & AY191653 & RBG Sydney; Stannary Hills, Qld \\
\hline A. inophloia & 10. Inopitys & DAS 99034 & AY191652 & Wild; Mt Garnett, N. Qld \\
\hline A. lehmanniana subsp. ecarinata & 11. Cylindropitys & KLW 9757 & AY191640 & RBG Annan; NE of Hopetoun, WA \\
\hline A. littoralis & 11. Cylindropitys & DAS 99002 & AY191627 & RTBG; source unknown \\
\hline A. littoralis & 11. Cylindropitys & KP7 & AY191651 & Kings Park, WA; source unknown \\
\hline A. luehmannii & 3. Platypitys & KLW 9782 & AY191673 & Wild; NE of Singleton, NSW \\
\hline A. mackliniana subsp. hirtilinea & 11. Cylindropitys & KLW 9883 & AY191633 & $\begin{array}{l}\text { Wild; Wonwondah-Dadswells } \\
\text { Bridge Road, Vic. }\end{array}$ \\
\hline A. mackliniana subsp. xerophila & 11. Cylindropitys & KLW 9884 & AY191629 & Wild; $\mathrm{N}$ of Gymbowen, Vic. \\
\hline A. media & 11. Cylindropitys & KLW 9745 & AY191623 & $\begin{array}{l}\text { RBG Annan; Wilsons Promontory, } \\
\text { Vic. }\end{array}$ \\
\hline A. microstachya 7216 & 13. Trachypitys & P Jobson 7216 & AY191621 & $\begin{array}{l}\text { Wild; Green Head to Coorow Road, } \\
\text { WA }\end{array}$ \\
\hline A. microstachya 7238 & 13. Trachypitys & P. Jobson 7238 & AY191620 & Wild; N of Mogumber, WA \\
\hline A. misera & 11. Cylindropitys & KLW 9882 & AY191630 & Wild; Stawell, Vic. \\
\hline A. monilifera & 11. Cylindropitys & DAS 99005 & AY191624 & RTBG; Safety Cove, Tas \\
\hline A. muelleriana subsp. muelleriana & 11. Cylindropitys & KLW 9754 & AY191648 & RBG Annan; Lobethal, SA \\
\hline A. nana & 12. Nanopitys & KLW 9762 & AY191622 & $\begin{array}{l}\text { RBG Annan; Newnes State Forest, } \\
\text { NSW }\end{array}$ \\
\hline A. ophiolitica & 11. Cylindropitys & KLW 9774 & AY191639 & Wild; NW of Curricabark, NSW \\
\hline A. paludosa & 11. Cylindropitys & DAS 99007 & AY191649 & RTBG; Gladstone, Tas \\
\hline A. paradoxa & 11. Cylindropitys & KLW 9752 & AY191632 & RBG Annan; Cranbourne, Vic. \\
\hline A. pinaster & 2. Oxypitys & KP8 & AY191674 & Kings Park, WA; source unknown \\
\hline A. portuensis & 11. Cylindropitys & KLW 9744 & AY191645 & RBG Sydney; Neilsen Park, NSW \\
\hline A. pusilla & 11. Cylindropitys & KLW 9760 & AY191631 & RBG Annan; Murrayville, Vic. \\
\hline A. rigida subsp. rigida & 11. Cylindropitys & KLW 9758 & AY191650 & RBG Annan; Barren Mtn, NSW \\
\hline A. rupicola & 11. Cylindropitys & KLW 9766 & AY191646 & RBG Annan; Mt Norman, Qld \\
\hline A. scleroclada & 5. Ceropitys & MD Crisp 4842A & AY191665 & CBG; Mt Ragged Range, WA \\
\hline A. simulans & 11. Cylindropitys & KLW 9770 & AY191636 & Wild; near Nabiac, NSW \\
\hline A. spinosissima & 4. Echinopitys & MD Crisp 5566 & AY191671 & CBG; E of Southern Cross, WA \\
\hline A. tessellata & 5. Ceropitys & KLW 9769 & AY191670 & RBG Annan; Mt Singleton, WA \\
\hline A. thalassoscopica & 11. Cylindropitys & P. Sharpe C2 & AY191642 & Wild; Mt Coolum Qld \\
\hline A. thuyoides & 14. Acanthopitys & KLW 9787 & AY191618 & RBG Annan; Stirling Range, WA \\
\hline A. tortiramula & 5. Ceropitys & KP9 & AY191662 & Kings Park, WA; source unknown \\
\hline
\end{tabular}


Table 1 (continued)

\begin{tabular}{|c|c|c|c|c|}
\hline Taxon & Section $^{\mathrm{a}}$ & Collection No. & GenBank & Source; locality ${ }^{\mathrm{b}}$ \\
\hline A. torulosa & 6. Allocasuarina & DAS 99036 & AY191659 & Wild; Lake Tinaroo, Qld \\
\hline A. trichodon & 9. Trachypitys & MD Crisp 5109 & AY191654 & CBG; NW of Cape Riche, WA \\
\hline A. verticillata & 8. Oopitys & KLW 9753 & AY191657 & RBG Annan; Orford, Tas \\
\hline A. verticillata & 8. Oopitys & KLW 9873 & AY191656 & Wild; Wombeyan Caves road, NSW \\
\hline A. zephyrea & 11. Cylindropitys & RTBG 97.0398 & AY191628 & RTBG; W. Coast Tas \\
\hline \multicolumn{5}{|l|}{ Casuarina } \\
\hline C. collina & & KLW 7722 & AY191697 & $\begin{array}{l}\text { Cult. Balmain; Riviere des Pirogues, } \\
\text { New Caledonia }\end{array}$ \\
\hline C. cristata & & DAS 99004 & AY191698 & RTBG; source unknown \\
\hline C. cristata & & KLW 9748 & AY191699 & RBG Annan; Mongarilby, Qld \\
\hline C. cunninghamiana subsp. unninghamiana & & KLW 9826 & AY191714 & Wild; Jackadgery, NSW \\
\hline C. cunninghamiana & & DAS 99006 & AY191707 & RTBG; source unknown \\
\hline C. equisetifolia subsp. equisetifolia & & DAS 99010 & AY191702 & Wild; Sarawak, Borneo \\
\hline C. equisetifolia subsp. equisetifolia & & Phil. Sp. 5 & AY191703 & Wild, Philippines \\
\hline C. equisetifolia subsp. equisetifolia & & DAS 99037 & AY191701 & Wild; Port Douglas Beach, Qld \\
\hline C. equisetifolia subsp. incana & & KLW 9765 & AY191700 & RBG Annan; Peregian Beach, QLD \\
\hline C. glauca & & KLW 9739 & AY191705 & Wild; RBG Sydney \\
\hline C. glauca & & KLW 9755 & AY191704 & Wild; RBG Annan \\
\hline C. obesa & & KLW 9743 & AY191709 & RBG Sydney; source unknown \\
\hline C. obesa & & KLW 9751 & AY191708 & RBG Annan; Leeman, WA \\
\hline C. oligodon subsp. oligodon & & KLW 9799 & AY191706 & RBG Sydney; source unknown \\
\hline C. 'parapotamia' $m s$ & & Phil. Sp. 6 & AY191712 & $\begin{array}{l}\text { Wild; Mt. Victoria, Palawan, } \\
\text { Philippines }\end{array}$ \\
\hline C. pauper & & NA Leist 82 & AY191711 & Wild; Nymagee_Cobar road, NSW \\
\hline C. 'riparia' $m s$ & & Phil. Sp. 14 & AY191713 & Wild; Luzon, Philippines \\
\hline C. 'timorensis' $m s$ & & KLW 9808 & AY191710 & Crossmaglen, NSW; Timor \\
\hline \multicolumn{5}{|l|}{ Ceuthostoma } \\
\hline C. palawanense & & Phil. Sp. 7 & AY191696 & $\begin{array}{l}\text { Wild; Mt Bloomfield, Palawan, } \\
\text { Philippines }\end{array}$ \\
\hline C. terminale & & & AY 033838 & Sogo et al. (2001) \\
\hline \multicolumn{5}{|l|}{ Gymnostoma } \\
\hline G. australianum & & DAS 99024 & AY191678 & Wild; Cape York, Qld \\
\hline G. australianum & & KLW 9742 & AY191679 & $\begin{array}{l}\text { RBG Sydney; Roaring Meg Creek, } \\
\text { Qld }\end{array}$ \\
\hline G. chamaecyparis & & KLW 9961 & AY191692 & Wild; Paagoumene, New Caledonia \\
\hline G. deplancheanum & & KLW 7704 & AY191681 & $\begin{array}{l}\text { RBG Sydney; Riviere des Lacs, New } \\
\text { Caledonia }\end{array}$ \\
\hline G. deplancheanum & & KLW 9741 & AY191682 & $\begin{array}{l}\text { RBG Sydney; Riviere Bleue, New } \\
\text { Caledonia }\end{array}$ \\
\hline G. glaucescens & & DAS 99025 & AY191684 & $\begin{array}{l}\text { Wild; Mt. Des Sources, New } \\
\text { Caledonia }\end{array}$ \\
\hline G. leucodon & & KLW 9936 & AY191683 & $\begin{array}{l}\text { Wild; Riviere des Pirogues, New } \\
\text { Caledonia }\end{array}$ \\
\hline G. 'mesostrobilum' ms & & Phil. Sp 1 & AY191685 & $\begin{array}{l}\text { Wild; Mt Victoria, Palawan, } \\
\text { Philippines }\end{array}$ \\
\hline G. 'mesostrobilum' ms & & T Livshultz 0064 & AY191686 & Wild; Tenom, Sabah \\
\hline G. nobile & & DAS 99008 & AY191687 & Wild; Sarawak \\
\hline G. nobile & & FRI 43903 & AY191688 & Cult; Peninsular Malaysia \\
\hline G. nodiflorum & & KLW 9917 & AY191691 & $\begin{array}{l}\text { Wild; Kone-Tiwaka road, New } \\
\text { Caledonia }\end{array}$ \\
\hline G. papuanum & & KLW 9740 & AY191695 & Moluccas, New Guinea \\
\hline G. poissonianum & & DAS 00013 & AY191689 & Wild; Mt Dzumac, New Caledonia \\
\hline G. poissonianum & & DAS 00014 & AY191690 & UTAS; New Caledonia \\
\hline G. sumatranum & & FRI 43901 & AY191693 & Cult; Peninsular Malaysia \\
\hline G. sumatranum & & $\begin{array}{l}\text { K Hill NSW } \\
442215\end{array}$ & AY191694 & Cult; Bogor BG. Java \\
\hline G. webbianum & & KLW 7724 & AY191680 & $\begin{array}{l}\text { RBG Sydney; Riviere des Pirogues, } \\
\text { New Caledonia }\end{array}$ \\
\hline Betula papyrifera & & DAS 00015 & AY191716 & RTBG; source unknown \\
\hline Betula papyrifera & & & U92853 & Manos and Steele (1997) \\
\hline Betula utilis & & RTBG 92.0414 & AY191717 & RTBG; source unknown \\
\hline Myrica cerifera & & & U92857 & Manos and Steele (1997) \\
\hline
\end{tabular}


Table 1 (continued)

\begin{tabular}{|c|c|c|c|c|}
\hline Taxon & Section $^{\mathrm{a}}$ & Collection No. & GenBank & Source; locality ${ }^{\mathrm{b}}$ \\
\hline Myrica gale & & KLW 9788 & AY191715 & RBG Tomah; source unknown \\
\hline Nothofagus cunninghamii & & & U92859 & Manos and Steele (1997) \\
\hline Ticodendron & & & U92855 & Manos and Steele (1997) \\
\hline Trigonobalanus & & & U92866 & Manos and Steele (1997) \\
\hline
\end{tabular}

${ }^{\mathrm{a}}$ Section refers to Allocasuarina only.

${ }^{\mathrm{b}}$ Bogor BG-Bogor Botanic Gardens, Java; CBG_-Australian National Botanic Gardens, Canberra; DAS_D.A. Steane; FRI-Forestry Research Institute Malaysia (FRIM), Kuala Lumpur, Malaysia; KP_Kings Park and Botanic Garden, Perth; E—east; N—north; NE-northeast; NSW-New South Wales; Qld-Queensland; R-River; RBG Annan-Royal Botanic Gardens Sydney (Mt Annan site); RBG Sydney-Royal Botanic Gardens Sydney (Sydney site); RBG Tomah-Royal Botanic Gardens Sydney (Mt Tomah site); RTBG-Royal Tasmanian Botanical Gardens, Hobart; SA_South Australia; SE-southeast; SW_-southwest; Tas-Tasmania; UTAS_School of Plant Sciences, University of Tasmania; WAWestern Australia.

Myrica) were collected from the wild or from cultivated specimens in botanic gardens (Table 1). Tissue was frozen in liquid nitrogen and stored at $-70^{\circ} \mathrm{C}$, dried using silica gel (Chase and Hills, 1991) or preserved in a CTAB/salt solution (Thomson, 2002).

DNA was extracted using a modified CTAB protocol (Doyle and Doyle, 1990). Approximately $0.1 \mathrm{~g}$ of green tissue ('needles') was ground under liquid nitrogen and was transferred to a $1.5 \mathrm{ml}$ eppendorf tube. Five hundred $\mu 1$ of hot $\left(65^{\circ} \mathrm{C}\right)$ CTAB buffer $(0.02 \mathrm{M}$ EDTA, $1.4 \mathrm{M} \mathrm{NaCl}, 0.1 \mathrm{M}$ Tris $\mathrm{pH} 8.0,2 \%$ CTAB, $0.7 \% \mathrm{v} / \mathrm{v}$ DTT, $2 \%$ soluble PVP) was added. The slurry was incubated at $65^{\circ} \mathrm{C}$ for $30 \mathrm{~min}$ with occasional shaking, followed by extraction with an equal volume of chloroform:isoamyl alcohol (24:1). Phases were separated by centrifugation for $10 \mathrm{~min}$ at $20,000 \mathrm{~g}$. The aqueous phase was removed and re-extracted with chloroform:isoamyl alcohol. Two volumes of cold $95 \%$ ethanol were added to the aqueous phase, mixed gently, and incubated on ice for $10 \mathrm{~min}$. The DNA was pelleted at $20,000 \mathrm{~g}$ for $5 \mathrm{~min}$. The pellet was washed briefly in $76 \%$ ethanol/ $0.01 \mathrm{M}$ sodium acetate and was re-centrifuged for $5 \mathrm{~min}$. The supernatant was removed, the pellet was air-dried and resuspended in $100 \mu \mathrm{l}$ TE $(10 \mathrm{mM}$ Tris, $\mathrm{pH}$ 8.0, 1 mM EDTA). When necessary, DNA was cleaned using a Prep-A-Gene DNA purification kit (Bio-Rad, USA) according to manufacturer's instructions.

A $1500 \mathrm{bp}$ fragment from the $3^{\prime}$ end of the $\operatorname{mat} \mathrm{K}$ gene was amplified using primers $1062 \mathrm{f}$ and $\operatorname{trnK} 2$ r (Fig. 1, Table 2) in the PCRs. Each PCR had a final volume of $50 \mu \mathrm{l}$ and contained 10-20 ng genomic DNA, $160 \mu \mathrm{M}$ each dATP, dCTP, dTTP, and dGTP, $4 \mathrm{mM} \mathrm{MgCl}_{2}$, $0.5 \mu \mathrm{M}$ forward (1062f) and reverse (trnK $2 \mathrm{r}$ ) primers, $1.25 \mathrm{U}$ Taq DNA polymerase (Qiagen, Germany) and $1 \times$ Qiagen Taq DNA polymerase buffer. Cycling conditions were: initial melting at $94^{\circ} \mathrm{C}$ for $5 \mathrm{~min} ; 30$ cycles of $94^{\circ} \mathrm{C}$ for $1 \mathrm{~min}, 45^{\circ} \mathrm{C}$ for $1 \mathrm{~min}, 72^{\circ} \mathrm{C}$ for $2 \mathrm{~min}$; final extension at $72^{\circ} \mathrm{C}$ for $15 \mathrm{~min}$. More recalcitrant samples (e.g. those prepared from silica-dried tissues) were amplified using Advantage 2 DNA polymerase (Clontech, USA). The $25 \mu \mathrm{l}$ reactions were prepared following the recommendations of the manufacturer: $0.4 \mu \mathrm{M}$ of each primer $(1062 \mathrm{f}$ and $\operatorname{trn\mathrm {K}} 2 \mathrm{r}), 400 \mu \mathrm{M}$ each $\mathrm{dNTP}, 1 \times$
Table 2

Primer sequence and location

\begin{tabular}{|c|c|c|}
\hline Primer & Sequence & Start $^{\mathrm{c}}$ \\
\hline $1062 \mathrm{f}$ & $5^{\prime}$ GTGGAAATTCCGTTTTCTCTACG $3^{\prime}$ & 1062 \\
\hline $1571 \mathrm{f}$ & 5' GGATCCTTTCATTCATT $3^{\prime}$ & 1571 \\
\hline $1908 \mathrm{r}$ & $5^{\prime}$ ACTAAYGGGATGGCCTRATGC $3^{\prime}$ & 1908 \\
\hline$m a t \mathrm{~K} 9 \mathrm{r}^{\mathrm{a}}$ & $5^{\prime}$ CAATCATTCGTGATTGGCCAG 3' & 2282 \\
\hline $\operatorname{trn} \mathrm{K} 2 \mathrm{r}^{\mathrm{b}}$ & $5^{\prime}$ AACTAGTCGGATGGAGTAG $3^{\prime}$ & 2573 \\
\hline
\end{tabular}

${ }^{a}$ Primer designed by Manos and Steele (1997).

${ }^{\mathrm{b}}$ Primer designed by Steele and Vilgalys (1994).

${ }^{\mathrm{c}}$ The base position at which the primer begins is relative to the Nicotiana sequence (Sugita et al., 1985).

Advantage 2 Polymerase mix and $1 \times$ Advantage 2 polymerase buffer. Cycling conditions were as follows: $95^{\circ} \mathrm{C}$ for $1 \mathrm{~min} ; 35$ cycles of $95^{\circ} \mathrm{C}$ for $30 \mathrm{~s}, 54^{\circ} \mathrm{C}$ for $30 \mathrm{~s}$, $68^{\circ} \mathrm{C}$ for $3 \mathrm{~min}$; final extension at $68^{\circ} \mathrm{C}$ for $3 \mathrm{~min}$. PCR products were cleaned using a QIAquick DNA Cleanup System (Qiagen, Germany).

PCR products were sequenced in both directions using a suite of 3-5 primers (Fig. 1, Table 2), including three that were custom-designed for this study (1062f, 1571f, 1908r) and two more conserved primers (matK9r and $\operatorname{trnK2}$ r; Manos and Steele, 1997; Steele and Vilgalys, 1994). PCR products were sequenced using an ABI Prism BigDye Terminator Cycle Sequencing Ready Reaction Kit (PE Biosystems, USA) following the recommendations of the manufacturer. Sequencing products were fractionated on a Perkin-Elmer 373 DNA sequencer. The mat K partial sequences for each sample were aligned and checked using Sequence Navigator version 1.0.1 (Applied Biosystems, USA). All sequences are lodged in GenBank (Accession Nos. AY191618AY191717). The data set is lodged in TreeBASE (study Accession No. S838; matrix Accession No. M1354).

Complete sequences from all samples were aligned by eye. Some of the sequences were identical or differed only by autapomorphies. To simplify the data set and accelerate analyses, taxa with identical sequences (ignoring autapomorphies) were pooled into single terminal units (Gymnostoma 1, Allocasuarina Group 1, Allocasuarina Group 2, Allocasuarina Group 3; see legend to Fig. 2). Additional matK sequences for $\mathrm{Ceu}$ thostoma terminale (Sogo et al., 2001) and outgroup taxa 


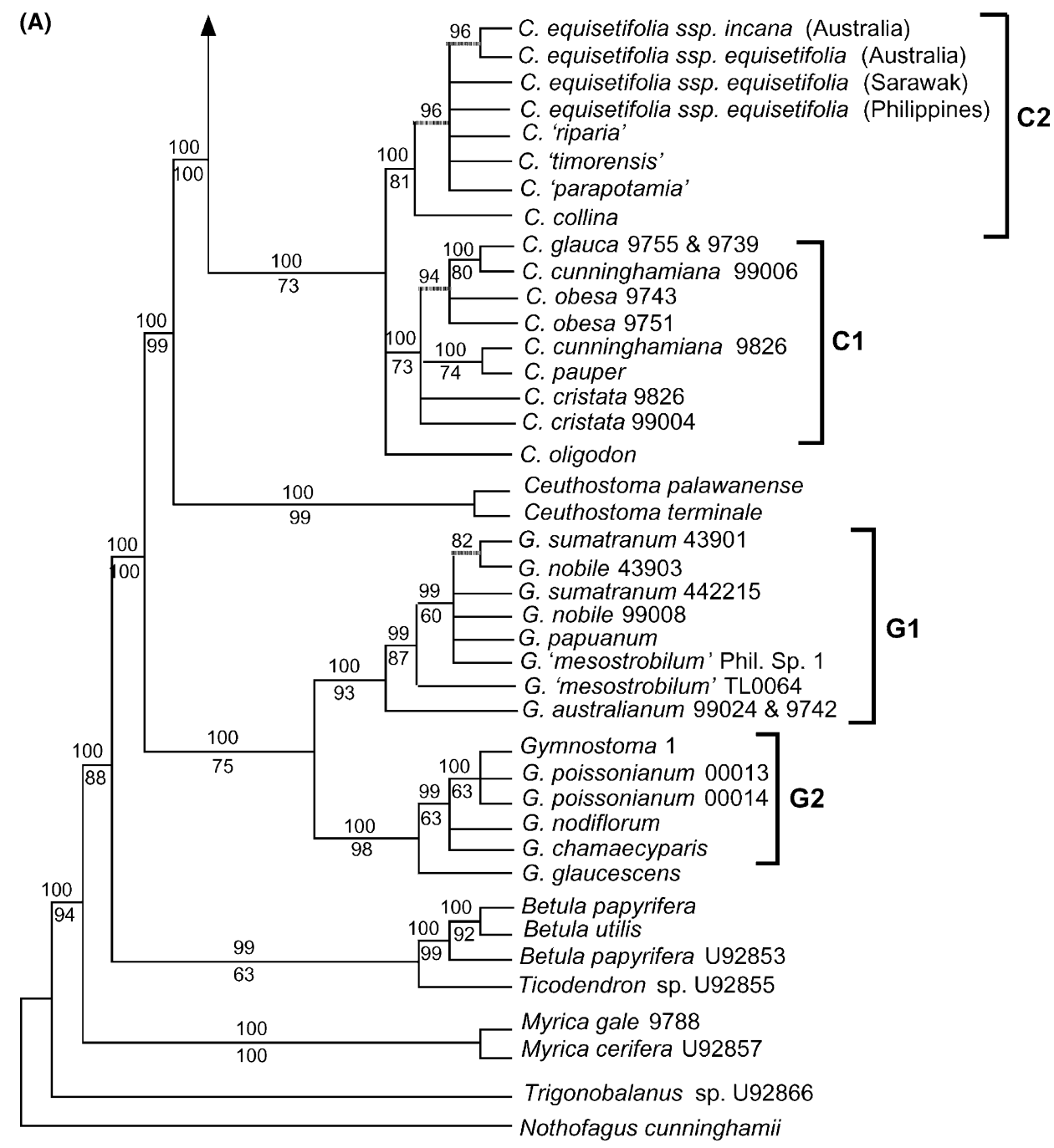

Fig. 2. Bayesian consensus of 8701 trees, and strict consensus cladogram of 93137 most parsimonious trees (length excluding autapomorphies $=464$; length including autapomorphies $=700 ; \mathrm{CI}$, excluding autapomorphies $=0.679$ ) derived from analyses of $m a t \mathrm{~K}$ sequence data from 98 samples of Casuarinaceae, and eight outgroup representatives. Bayesian posterior probability values greater than $50 \%$ are shown above branches; bootstrap values greater than $50 \%$ for the cladistic analysis are shown below branches. Dotted lines indicate branches that were supported by the Bayesian analysis but collapsed in the cladistic strict consensus. An asterisk indicates a clade that was found in the strict consensus of the cladistic analysis, but was not found by Bayesian analysis. (A) Lower portion of the consensus tree, showing outgroup taxa, Gymnostoma and Casuarina. 'Gymnostoma 1' includes four samples of Gymnostoma that have identical sequences: G. deplancheanum KLW 7704, G. deplancheanum KLW 9741, G. leucodon KLW 9936 and G. webbianum KLW 7724. See text for discussion of clades G1, G2, C1, and C2. (B) Upper portion of the consensus tree, showing Allocasuarina. The number in front of each species name indicates the section of Allocasuarina to which the species belongs (see Table 1). 'Allocasuarina Group 1,' 'Allocasuarina Group 2,' and 'Allocasuarina Group 3' comprise six, four, and four samples, respectively, of section Cylindropitys (Section 11) that have identical sequences. 'Allocasuarina Group 1': A. duncanii, A. grampiana, A. littoralis DAS 99002, A. media (contains an autapomorphy), A. monilifera and A. zephyrea. 'Allocasuarina Group 2': A. simulans, A. diminuta subsp. annectens, A. distyla, A. ophiolitica. 'Allocasuarina Group 3': A. misera, A. mackliniana 9883 (contains an autapomorphy), A. mackliniana 9884, A. pusilla and A. paradoxa. See text for discussion of clades A1, $\mathrm{A} 2$, and $\mathrm{A} 3$.

[Betula, Myrica, Nothofagus, Ticodendron, and Trigonobalanus; (Manos and Steele, 1997)] were obtained from GenBank (Table 1) and added to the data set. Fifteen indels (insertion/deletion events), of which seven were autapomorphic, were coded as binary characters. The sequence characters for these indels were excluded from the analysis, such that each indel received equal weighting regardless of the number of nucleotides in- volved. Phylogenetic analyses were carried out using PAUP* 4.0 b3 (Swofford, 1999).

Percentage pairwise base differences were calculated using the PAIRWISE BASE FREQUENCIES option in the DATA menu of PAUP* $4.0 \mathrm{~b} 3$. These values are corrected for gaps and ambiguities.

Maximum parsimony analyses involved heuristic search strategies as described by Catalán et al. (1997); 


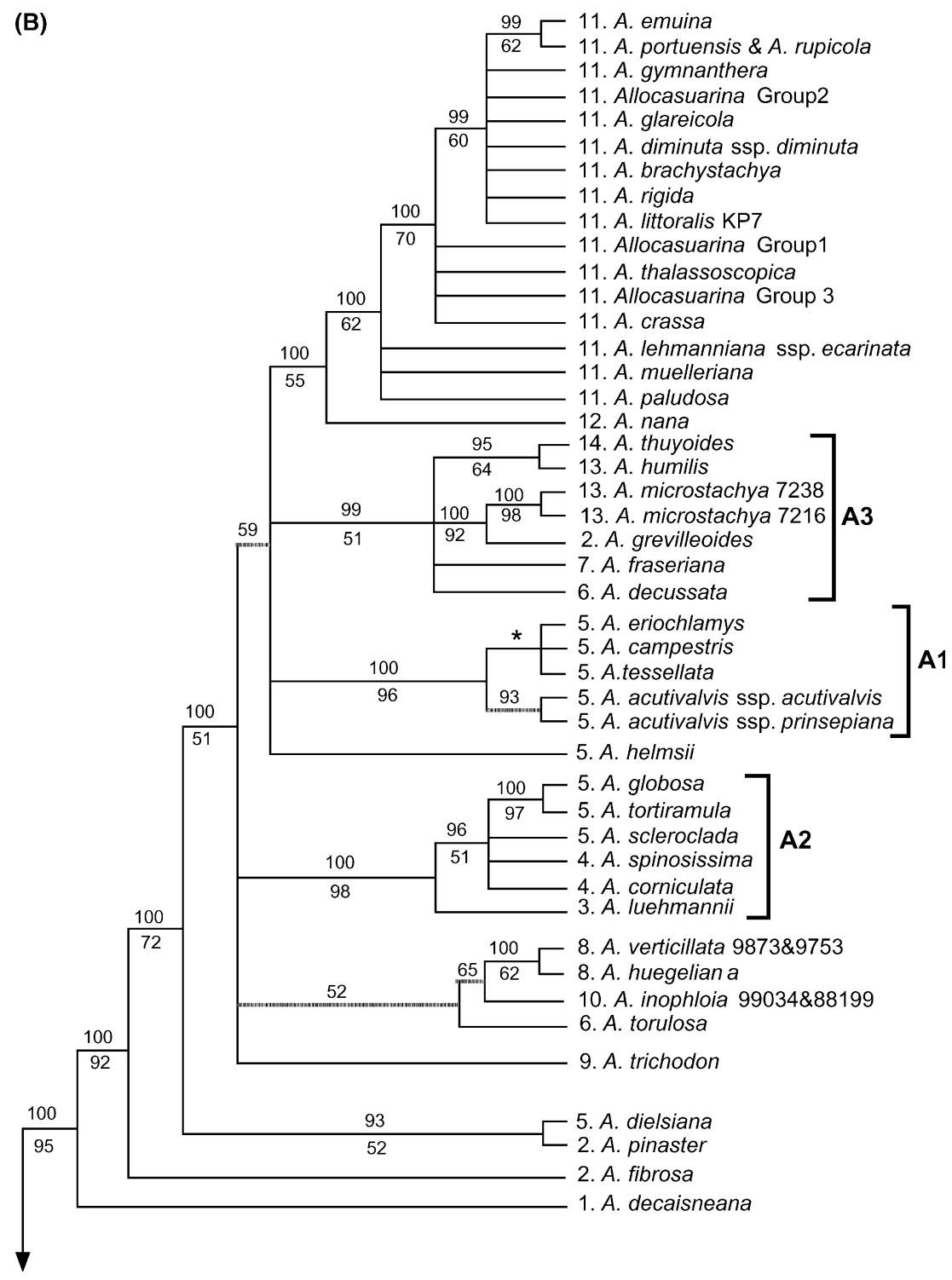

Fig. 2. (continued)

(see also Steane et al., 2002). The data set was bootstrapped using 10,000 replicates of the 'fast, stepwise' option of PAUP* 4.0b3 (see Mort et al., 2000).

Bayesian phylogenetic analyses were conducted with MrBayes 2.01 (Huelsenbeck and Ronquist, 2001). The equal rates model (Kimura, 1981) with unequal base frequencies $(B A E F R E Q=E M P I R I C A L)$ was selected as the best fit model of nucleotide substitution (Modeltest v. 3.06; Posada and Crandall, 1998). Bayesian analysis was started from a random tree and run for $10^{6}$ generations. We used four incrementally heated Markov chains, employing the default heating values. The Markov chains were sampled at intervals of 100 generations, resulting in a final set of 10,001 sample points. Stationarity was reached after 130,000 generations; 1300 sample points were discarded as burn-in. The remaining sample points were used to generate a
$50 \%$ majority rule consensus. The percentage of sample points recovering any particular clade represents that clade's posterior probability (Huelsenbeck and Ronquist, 2001).

\section{Results}

A total of 106 sequences (98 Casuarinaceae and eight outgroup sequences) were included in the data set. Pooling of identical sequences resulted in 86 operational taxonomic units (OTUs) and 1502 aligned bases. Actual sequence lengths were generally much shorter than $1502 \mathrm{bp}$ because of the large number of gaps introduced by highly divergent taxa. Most sequences were $1400 \mathrm{bp}$. There were 244 potentially phylogenetically informative characters included in the analysis. 
Table 3

Corrected percentage pairwise differences within and between genera

\begin{tabular}{|c|c|c|c|c|c|c|c|c|}
\hline & 1 & 2 & 3 & 4 & 5 & 6 & 7 & 8 \\
\hline 1. Allocasuarina & $\begin{array}{l}0-1^{\mathrm{a}} \\
1-2^{\mathrm{b}}\end{array}$ & & & & & & & \\
\hline 2. Casuarina & $2-3$ & $0-1$ & & & & & & \\
\hline 3. Ceuthostoma & 4 & 3 & 0 & & & & & \\
\hline 4. Gymnostoma & 4 & $3-4$ & 3 & $0-1$ & & & & \\
\hline 5. Betula & 7 & 7 & $5-6$ & $5-6$ & 0 & & & \\
\hline 6. Trigonobalanus & $7-8$ & 7 & 6 & 6 & 4 & - & & \\
\hline 7. Myrica & 9 & 8 & $7-8$ & 7 & 5 & 7 & 1 & \\
\hline 8. Ticodendron & 13 & 13 & 12 & 11 & 10 & 10 & 11 & - \\
\hline 9. Nothofagus & 15 & 15 & 14 & 14 & 12 & 13 & 12 & 16 \\
\hline
\end{tabular}

${ }^{\mathrm{a}}$ Within sections.

${ }^{\mathrm{b}}$ Between sections.

Pairwise sequence differences, corrected for gaps and ambiguities, are shown in Table 3. Within Casuarinaceae these values ranged from $0 \%$ between species within a genus to $4 \%$ between genera. Among the outgroup genera, Betula was the most similar to Casuarinaceae (5-7\% base differences), as was also found by Manos and Steele (1997) and other workers; Nothofagus was the least similar, with $14-15 \%$ pairwise differences. Despite the low percentage difference among Casuarinaceae taxa, there were sufficient phylogenetically informative characters to produce well-resolved consensus cladograms with good statistical support for many clades (Fig. 2).

Maximum parsimony (MP) and Bayesian inference yielded consensus cladograms with highly congruent topologies, the latter being slightly more resolved. The strict consensus from the MP analysis and the majority rule consensus from the Bayesian analysis are shown in Fig. 2. Bayesian analysis resulted in a mean $\ln L$ value of -6509.36 , variance of 88.94 and a $95 \%$ credibility interval of -6528.90 to -6491.99 . Two other Bayesian analyses, one using equal rates and equal base frequencies, the other using a gamma distribution of rate variation, yielded respectively identical and almost identical topologies to that shown in Fig. 2, but lower $\ln L$ values (results not shown). The heuristic MP analysis yielded 93137 most parsimonious trees of length 464 (excluding autapomorphies; 700 including autapomorphies), consistency index excluding autapomorphies, $\mathrm{CI}=0.679$ and retention index, $\mathrm{RI}=0.919$.

Within the ingroup, the four genera are supported as monophyletic, with moderate $73 \%$ in Casuarina, $75 \%$ in Gymnostoma) to strong (95\% in Allocasuarina, $99 \%$ in Ceuthostoma) bootstrap support and strong $(100 \%)$ posterior probability values (Fig. 2). Allocasuarina and Casuarina form a clade (100\% bootstrap support, 100\% posterior probability, Fig. 2; branch support $=12$ steps, Fig. 3A). Ceuthostoma is sister to Allocasuarina $+\mathrm{Ca}$ suarina (this clade has 99\% bootstrap support, $100 \%$ posterior probability, Fig. 2A; branch support $=42$ steps, Fig. 3A), and Gymnostoma is sister to Ceuthos- toma + Casuarina + Allocasuarina (this clade has $100 \%$ bootstrap support, 100\% posterior probability, Fig. 2A; branch support $=21$ steps, Fig. 3A). Within each of the large clades (i.e., Gymnostoma, Casuarina, and Allocasuarina) there is distinct phylogenetic structure. Gymnostoma comprises two major clades, $\mathrm{G} 1$ and $\mathrm{G} 2$, both of which have good bootstrap (Fig. 2A) and branch (Fig. 3A) support and $100 \%$ posterior probability (Fig. 2A). Clade G1 comprises Malesian species ( $G$. nobile, $G$. sumatranum, and G. 'mesostrobilum') as well as G. australianum from Northern Australia. The other clade, G2, is purely New Caledonian (G. chamaecyparis, G. deplancheanum, G. glaucescens, G. leucodon, G. nodiflorum, G. poissonianum, and G. webbianum).

Similarly, geographic partitioning of taxa also occurs in Casuarina. Clade $\mathrm{Cl}$ comprises only Australian species of Casuarina. Clade C2 is more cosmopolitan, with species from Timor, the Philippines and New Caledonia, as well as the widespread Casuarina equisetifolia (four representatives from Australia, Philippines and Sarawak (Borneo)). The relationships within these two main clades remain unresolved, as does the phylogenetic position of the New Guinean species, Casuarina oligodon (in a hard polytomy, i.e. there are insufficient data to resolve the node; there is no conflict between characters).

Within Allocasuarina several small clades have high bootstrap values but most clades have bootstrap proportions less than $70 \%$ (Fig. 2B) and there are frequent hard polytomies. Posterior probability values for many of these clades, however, is high $(>95 \%)$. Clades that were found by Bayesian analysis that were not found by cladistic analysis usually had a relatively low posterior probability (Fig. 2B, branches with dotted lines). Similarly, the clade that was found by cladistic analysis that was not found by Bayesian analysis had a bootstrap value $<50 \%$ (Fig. 2B, branch marked with asterisk). The taxonomic sections delimited by Wilson and Johnson (1989) exhibit some phylogenetic integrity. The largest section, Cylindropitys (section 11; 27 out of 30 species represented) appears to be monophyletic; the monotypic 
(A)

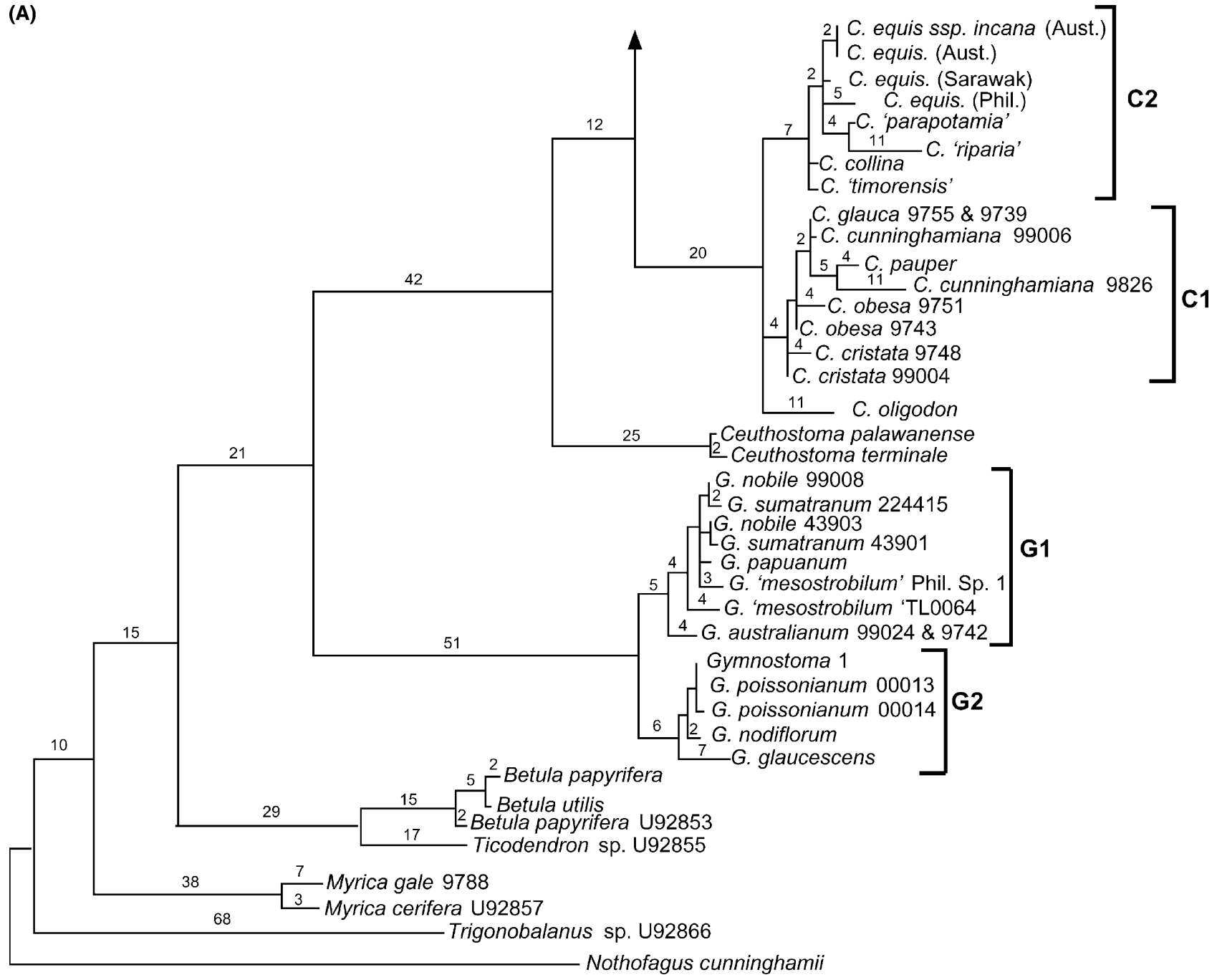

Fig. 3. Phylogram (including autapomorphies) of one of the 57120 trees (see legend to Fig. 2) obtained by cladistic analysis of $m a t \mathrm{~K}$ data from 97 samples of Casuarinaceae and eight outgroup representatives. Branch lengths are shown above branches. Branches without digits above them are 1 step long. (A) Lower portion of phylogram, showing outgroup taxa, Gymnostoma and Casuarina. 'C. equis.' = C. equisetifolia subsp. equisetifolia. See legend to Fig. 2 for further details of annotations. (B) Upper portion of the phylogram showing Allocasuarina. See legend to Fig. 2 for explanation of annotations.

section Nanopitys (section 12) appears to be sister to Cylindropitys (11). The small section Trachypitys (section 13; two of three species represented) appears to be polyphyletic: Allocasuarina microstachya and A. humilis appear in a clade (A3; Fig. 2B) with the monotypic sections Acanthopitys (section 14) and Amorphopitys (section 7), as well as representatives of sections $O x y$ pitys (section 2) and Allocasuarina (section 6). Of the remaining sections, Ceropitys (section 5) is the largest with nine species, and appears to be polyphyletic (Figs. 2 and 3). Species from section Ceropitys arise from four nodes on the cladogram. Within Ceropitys there is a well-supported monophyletic group (A1; bootstrap support $=96 \%$, posterior probability $=100 \%$, Fig. 2B; branch support $=5$, Fig. 3B) comprising $A$. eriochlamys, A. campestris, A. tessellata, and two subspecies of $A$. acutivalvis. The other species of section Ceropitys associate with species of sections Oxypitys (section 2), Platypitys (sect. 3) and Echinopitys (sect. 4). Three other members of section 5, Ceropitys (A. globosa, A. tortiramula, and $A$. scleroclada) appear in a well-supported clade (A2; bootstrap percentage $=98 \%$, posterior probability $=100 \%$, Fig. 2B; branch support $=4$, Fig. 3B) with Allocasuarina luehmannii (the sole member of section 3, Platypitys, from eastern Australia) plus both species from section 4, Echinopitys (A. corniculata and $A$. spinosissima). The position of $A$. helmsii (section Ceropitys) is unresolved, while $A$. dielsiana grouped with A. pinaster (section 2, Oxypitys; but bootstrap support is only $50 \%$ ). Another apparently polyphyletic section is Oxypitys (section 2), with one of its species, Allocasuarina fibrosa, apparently sister to all Allocasuarina except 


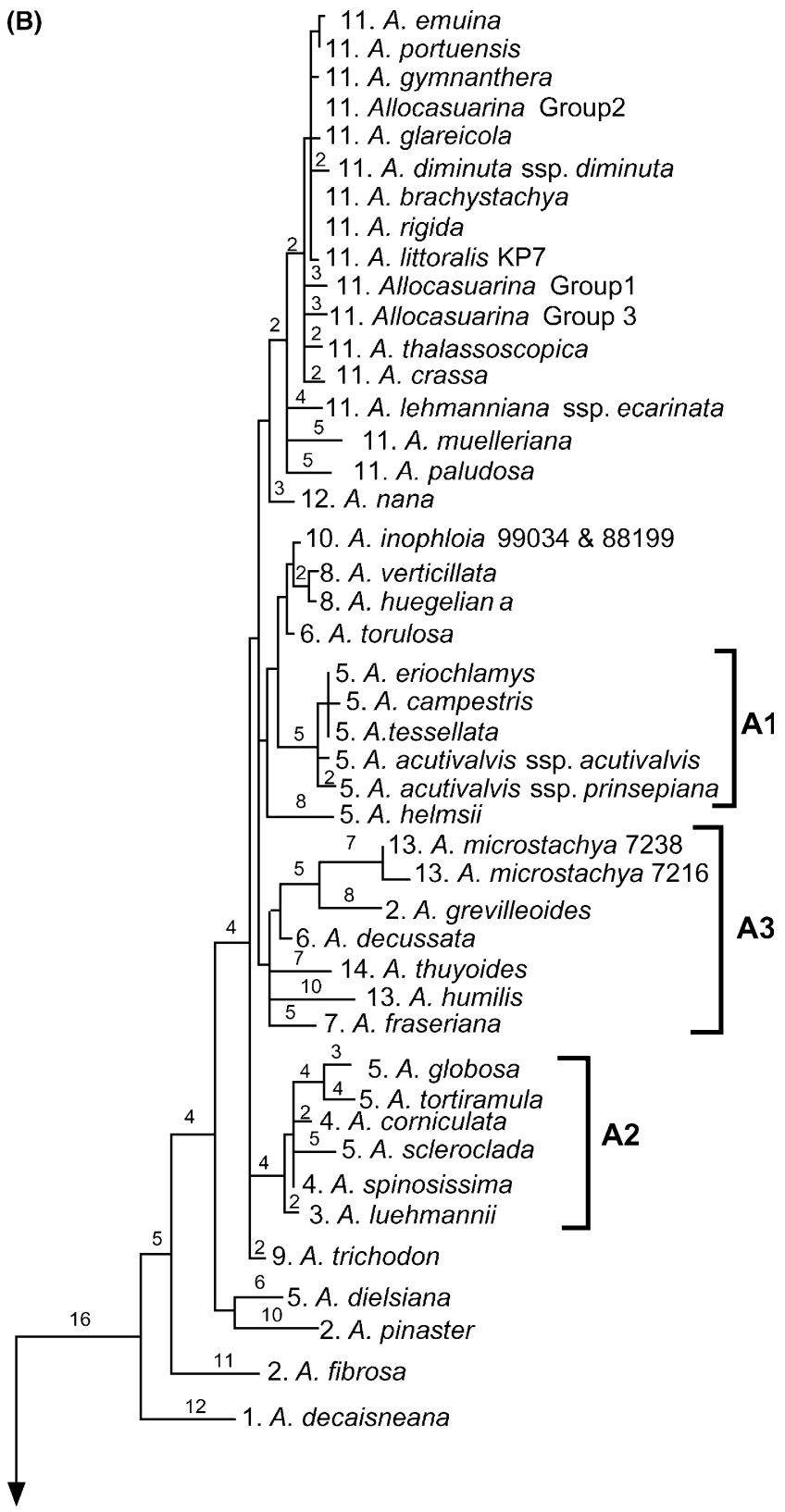

Fig. 3. (continued)

A. decaisneana (section 1, Dolichopitys). One species of section Oxypitys, Allocasuarina grevilleoides, is sister to A. microstachya (section 13, Trachypitys) (bootstrap support $=92 \%$, posterior probability $=100 \%$, Fig. 2B; branch support $=5$ steps, Fig. 3B). This clade falls within a partly unresolved clade (A3), comprising species from sections Allocasuarina (section 6 -one of two species), Amorphopitys (section 7-monospecific), Trachypitys (section 13-two out of three species were sampled), and Acanthopitys (section 14 -monospecific). Clade A3 has poor bootstrap support (51\%) but high posterior probability $(99 \%$; Fig. 2B). The scattered placing of species of section Oxypitys suggests the need for re-evalution of this section, notably whether the morphological similarities such as unusual branchlet arrangement are convergent.

\section{Discussion}

Bayesian inference is a relatively recent addition to the analytical toolbox for phylogenetics. Like maximum likelihood analysis, Bayesian estimation is based on the likelihood function. However, whereas a maximum likelihood value represents the probability of the data given a hypothesis (i.e., a tree), Bayesian inference provides the probability of a hypothesis (i.e., a tree) given the data (Lewis, 2001). One very attractive advantage of Bayesian analysis over maximum likelihood is that it requires fewer computational resources, so that large data sets can be analysed more readily. Also, because the estimation of branch support accompanies tree estimation, additional bootstrap analyses are not required. Likelihood-based phylogenetic analyses provide alternatives to parsimony analysis that tend to be less sensitive to artifacts like long branch attraction. In this study a maximum likelihood analysis was not possible because of the large size of the data set. Bayesian inference provided a practical alternative, with the resulting phylogeny providing additional support for the major clades identified by maximum parsimony analysis.

The phylogeny of the Casuarinaceae presented here offers strong support for the four genera defined by Johnson and Wilson (1989). Gymnostoma is sister to the other three genera, and this supports the hypothesis that the encryption of stomata in the other three genera has a single origin. This transition can probably be dated to the Late Oligocene at least, based on the recent discovery of Casuarinaceae branchlets with encrypted stomata in sediments of this age from Riversleigh in northeastern Australia (Guerin, 2001). The fossil record of Gymnostoma significantly precedes this date (Late Paleocene; Scriven and Hill, 1995), but it still cannot be determined from the fossil record whether encryption of stomata is the ancestral or derived condition in the family. Within the clade containing Ceuthostoma $+\mathrm{Al}$ locasuarina + Casuarina, Ceuthostoma is sister to the other two genera, suggesting that four leaves (represented by the longitudinal phyllichina; Johnson and Wilson, 1989) per whorl is the ancestral condition, since this also occurs in Gymnostoma. This suggests that more than four leaves per whorl is the derived condition. Increasing the number of leaves per whorl allows for more developed encryption of stomata. In plants with four leaves per whorl, the stems tend to be square and although shallow furrows may develop (e.g., in some Gymnostoma species), the stomata do not tend to be inside the furrows. Increasing the number of articles 
allows for a rounder, more sclerenchymatous stem (see Johnson and Wilson, 1989) and reduces the amount of space between the leaves. Furrows in such a stem take up a greater proportion of the room between phyllichnia, increasing the likelihood that stomata will occur inside the furrows. This encryption of stomata, and increased amounts of sclerenchyma, would have had a selective advantage in a dry climate, eventually leading to very closed furrows with highly protected stomata.

Within Gymnostoma, two clades can be identified, one in New Caledonia and one in Australia/Malesia. Recently, Swenson et al. (2001) hypothesised that Nothofagus had reached New Caledonia via long distance dispersal from New Zealand, and that the closely related group of extant species there have probably evolved from a single colonist species. A similar scenario may well be true for Gymnostoma-as well as New Caledonian species of Araucaria, Agathis (Setoguchi et al., 1998) and Metrosideros (Wright et al., 2000, 2001) -and would explain the well defined clade of extant species in New Caledonia. This hypothesis requires further testing to distinguish it from the possiblity that the New Caledonian species are descendents from a single Gondwanan ancestor. It is significant that while the Casuarinaceae have a fossil record in New Zealand that dates back to the Paleocene (ca 55-65 mya; Macphail et al., 1994), it does not extend back to the time when New Zealand is believed to have separated from Gondwana, ca. 85-90 mya. This suggests a requirement for dispersal (from Australia to New Zealand; see Winkworth et al., 2002) in the family at an early stage (or a poorly known fossil record, e.g., see Crisp (1991)). The wide distribution of $C$. equisetifolia today is a modern example of the ability of species within the family to achieve dispersal. The two subspecies of $C$. equisetifolia, subsp. equisetifolia and subsp. incana, in this study, collected from Queensland, Australia, group with other Casuarina species from the Indomalesian region. Casuarina equisetifolia is dispersed by wind and sea (and possibly also by humans) and is found on tropical and subtropical coastlines of northern and northeastern Australia, Burma to Vietnam, Malesia, Melanesia and Polynesia; records from India, the Mascarenes and other tropical areas are regarded as the result of relatively recent introductions, either deliberate or accidental (Johnson and Wilson, 1989). The grouping of C. equisetifolia with Indomalesian species (Clade C2; Fig. 2A) rather than the endemic Australian species (Clade C1; Fig. 2A) suggests that $C$. equisetifolia is either a relatively new species that came to Australia from Indomalesia, or evolved in Australia (from an ancestor that was also common to the other Indomalesian taxa) and then dispersed to other regions.

The mat K results of Sogo et al. (2001) do not support the division of Casuarina into clades $\mathrm{C} 1$ and $\mathrm{C} 2$. This appears to be because their data set $(1014 \mathrm{bp})$ did not include a highly informative region of ca. $300 \mathrm{bp}$ at the $3^{\prime}$ end of the mat $\mathrm{K}$ gene. Inclusion of the Sogo et al. (2001) Casuarina sequences in our data set resulted in conspecific samples grouping together in clades $\mathrm{C} 1$ and C2 (data not shown).

On morphological grounds, C. cunninghamiana and C. oligodon might be expected to group with clade $\mathrm{C} 2$ and $C$. collina with clade $\mathrm{C} 1$. Our molecular data, however, suggest that phylogenetic groupings coincide more closely with the species' biogeography than with morphological traits, suggesting morphological convergence between species. Similar phenomena have been reported for other taxa [e.g., Banksia (Mast and Givnish, 2002); Clerodendrum (Steane et al., 1999); Costaceae (Specht et al., 2001)]. Our results call for a reexamination of morphological characters in Casuarina and study of additional genes to verify the results reported here.

Casuarina and Allocasuarina are sister taxa, quite similar both in morphology and in matK sequence data. Since the divergence of Ceuthostoma and Casuarina + Allocasuarina there has been a major radiation of species, especially in Allocasuarina. The xeromorphic characters developed in the 'cryptostomes' allowed $\mathrm{Ca}$ suarina and especially Allocasuarina to diversify and exploit the increasing variety of niches that arose with the gradual desiccation of Australia over the past 30 million years. The dark, shiny samaras in Allocasuarina, for example, are unique in the family. The inflated cells of their mesocarp layer have walls that are spirally thickened; these thickenings expand through the weak exocarp and hold water around the fruit when moistened (Ladd, 1989). The spirals are also present in $\mathrm{Ca}$ suarina and water is held by them, but these species have a stronger exocarp so that the spirals do not break through the exocarp and trap less water than in Allocasuarina. The composition of the spirals is suggested to be cellulosic by Ladd (1989) rather than hygroscopic polysaccharides as thought by Torrey (1983). The end result is a moist, mucilaginous-looking samara; as suggested by Turnbull and Martensz (1983) and Torrey (1983), this could be considered an adaptation for rapid germination and establishment in habitats with erratic water supply, as found in so many parts of Australia.

Johnson and Wilson (1989) recognised 14 sections in Allocasuarina. Although the mat $\mathrm{K}$ data do not provide enough information to resolve fully the relationships among the sections, they do indicate that section 11 , Cylindropitys, is monophyletic, while the two other large sections (Ceropitys and Oxypitys) appear to be polyphyletic. The species in Clade A3, while sufficiently morphologically different to be placed by Johnson and Wilson (1989) into separate sections, have overlapping distributions in Western Australia. This raises the possibility that, as for Gymnostoma and Casuarina, the species phylogeny within Allocasuarina is more closely 
aligned with biogeography than with morphology. However, while the geographic partitioning within Gymnostoma and Casuarina is most likely due to ancient biogeography (e.g., vicariant evolution, long distance dispersal), the events leading to the biogeographic patterns seen in Allocasuarina are possibly more recent and may not reflect species phylogeny per se. It is possible that within Allocasuarina, reproductive isolation between some species is incomplete, and interspecific hybridisation may occur among some sympatric species from different sections (e.g., the Western Australian species in clade A3), a phenomenon that could result in the sharing of chloroplast genomes among morphologically distinct taxa. Extensive sharing of chloroplast haplotypes-attributed to some form of horizontal transfer, such as hybridisation-between species has been observed among Tasmanian species of Eucalyptus (Steane et al., 1998; McKinnon et al., 2001), as well as northern hemisphere Armeria (Gutiérrez Larena et al., 2002), Quercus (Belahbib et al., 2001) and Pinus (Matos and Schaal, 2000). Some Western Australian eucalypts also demonstrate extensive sharing of chloroplast haplotypes, but in this case lineage sorting, rather than hybridisation, has been proposed as the most likely mechanism [Dean Nicolle, (Flinders University, South Australia), pers. comm.]. We are undertaking further work using more variable DNA sequences [e.g., the $p s b \mathrm{~A}-t r n \mathrm{H}$ spacer region of the chloroplast DNA and the nuclear ribosomal internal transcribed spacer (ITS) regions] that may help to clarify the intersectional relationships within Allocasuarina.

\section{Acknowledgments}

We would like to thank the following individuals and institutions for providing us with plant material for the study: David Albrecht (Alice Springs Herbarium, Northern Territory); Australian National Botanic Gardens, Canberra; Bill Baker and Mark Chase (RBG Kew, England); Tim Brodribb (Harvard University, USA); Richard Chung (Forest Research Institute, Kuala Lumpur, Malaysia); Andrew Ford and Bernie Hyland (CSIRO, Atherton, Queensland); Greg Jordan (University of Tasmania, Australia); Kings Park and Botanic Garden, Perth, Western Australia; Tanya Livshultz (LH Bailey Hortorium, USA); Domingo Madulid (National Museum, Manila, Philippines); Kay Morgan (Sydney, NSW); Royal Botanic Gardens Sydney, New South Wales (especially Peter Jobson, Joy Everett, Ken Hill, Natasha Leist, Steve Skinner, and Gillian Towler); Royal Tasmanian Botanical Garden, Hobart, Tasmania; Philip Sharpe (Coolum, Queensland); Runi Sylvester, Pusat Penyelidikan Hutan, Sarawak; Luke Vanzino, Hobart, Tasmania. Our thanks also go to Annette Blanchfield, Peter Bundock and Ashley Edwards for technical assistance. This research was funded by the Australian Biological Resources Study (ABRS), 1999 2000 and the Australian Research Council.

\section{References}

Archangelsky, S., 1973. Palinologia del paleoceno de Chubut. 1. Descripciones sistematicas. Ameghiniana 10, 339-399.

Belahbib, N., Pemonge, M.-H., Ouassou, A., Sbay, H., Kremer, A., Petit, R.J., 2001. Frequent cytoplasmic exchanges between oak species that are not closely related: Quercus suber and Q. ilex in Morocco. Mol. Ecol. 10, 2003-2012.

Campbell, L.D., Holden, A.M., 1984. Miocene Casuarinaceae fossils from Southland and Central Otago, New Zealand. New Zeal. J. Bot. 22, 159-167.

Catalán, P., Kellogg, E.A., Olmstead, R.G., 1997. Phylogeny of Poaceae subfamily Pooideae based on chloroplast $n d h \mathrm{~F}$ gene sequences. Mol. Phylogenet. Evol. 8, 150-166.

Chase, M.W., Hills, H.H., 1991. Silica gel: an ideal material for field preservation of leaf samples for DNA studies. Taxon 40, 215-220.

Christophel, D.C., 1980. Occurrence of Casuarina megafossils in the Tertiary of south-eastern Australia. Aust. J. Bot. 28, 249-259.

Christophel, D.C., 1989. Evolution of the Australian flora through the Tertiary. Pl. Syst. Evol. 162, 63-78.

Coetzee, J.A., Muller, J., 1984. The phytogeographic significance of some extinct Gondwana pollen tyeps from the Tertiary of the southwestern Cape (South Africa). Ann. Missouri Bot. Gard. 71, 1088-1099.

Coetzee, J.A., Praglowski, J., 1984. Pollen evidence for the occurrence of Casuarina and Myrica in the Tertiary of South Africa. Grana 23, 23-41.

Crisp, M., 1991. Samaras and feathers, or Casuarinas on the wing? Aust. Syst. Bot. Soc. Newsl. 67, 23-25.

Dilcher, D.L., Christophel, D.C., Bhagwandin, H.O., Scriven, L.J., 1990. Evolution of the Casuarinaceae: morphological comparisons of some extant species. Am. J. Bot. 77, 338-355.

Doyle, J.J., Doyle, J.L., 1990. Isolation of plant DNA from fresh tissue. Focus 12, 13-15.

Frenguelli, J., 1943. Restos de Casuarina en el Mioceno de el Mirador, Patagonia central. Notas del Museo de la Plata, Paleontologia 56, 349-354.

Guerin, G., 2001. Plant megafossils from the Oligocene of Riversleigh, Queensland and Little Rapid River, Tasmania. B.Sc. Hons. Thesis, Department of Environmental Biology, University of Adelaide.

Gutiérrez Larena, B., Fuertes Aguilar, J., Nieto Feliner, G., 2002. Glacial-induced altitudinal migrations in Armeria (Plumbaginaceae) inferred from patterns of chloroplast DNA haplotype sharing. Mol. Ecol. 11, 1965-1974.

Hill, R.S., MacPhail, M.K., 1983. Reconstruction of the Oligocene vegetation at Pioneer, northeast Tasmania. Alcheringa 7, 281-299.

Hilu, K.W., Liang, H., 1997. The matK gene: sequence varition and application in plant systematics. Am. J. Bot. 84, 830-839.

Huelsenbeck, J.P., Ronquist, F.R., 2001. MRBAYES: Bayesian inference of phylogeny. Bioinformatics 17, 751-755.

Hwang, Y.H., 1990. The Casuarinaceae: a palynological review. Aust. Syst. Bot. Soc. Newsl. 62, 4-5.

Hwang, Y.H., 1991a. The Casuarinaceae: a biogeographic-based theory. Aust. Syst. Bot. Soc. Newsl. 68, 14-16.

Hwang, Y.H., 1991b. The Casuarinaceae: a few problematic fossil records. Aust. Syst. Bot. Soc. Newsl. 66, 15-16.

Hwang, Y.H., 1992. The Casuarinaceae: Allocasuarina is unsupported. Aust. Syst. Bot. Soc. Newsl. 70, 16-18.

Johnson, L.A.S., 1991. Casuarinaceae-some clarifications. Aust. Syst. Bot. Soc. Newsl. 67, 25-26. 
Johnson, L.A.S., Wilson, K.L., 1989. Casuarinaceae: a synopsis. In: Crane, P.R., Blackmore, S. (Eds.), Evolution, Systematics, and Fossil History of the Hamamelidae, Volume 2: "Higher Hamamelidae." Systematics Association Special Volume No. 40B, Clarendon Press, Oxford, pp. 167-188.

Jordan, G.J., 1997. Evidence of plant extinction and diversity from Regatta Point, western Tasmania, Australia. Bot. J. Linn. Soc. 123, 45-71.

Kimura, M., 1981. Estimation of evolutionary distances between homologous nucleotide sequences. Proc. Natl. Acad. Sci. USA 78, 454-458.

Ladd, P.G., 1989. The status of Casuarinaceae in Australian forests. In: Frawley, K.J., Semple, N.M. (Eds.), Australia's Ever Changing Forests. Special Publn No. 1, pp. 63-85. Dept of Geog. and Oceanography, Aust. Defence Force Academy, Campbell, ACT, Australia.

Lewis, P.O., 2001. Phylogenetic systematics turns over a new leaf. Trends Ecol. Evol. 16, 30-37.

Macphail, M.K., Alley, N.F., Truswell, E.M., Sluiter, I.R.K., 1994. Early tertiary vegetation: evidence from spores and pollen. In: Hill, R.S. (Ed.), History of the Australian Vegetation: Cretaceous to Recent. Cambridge University Press, Cambridge, pp. 189-261.

Manos, P.S., Steele, K.P., 1997. Phylogenetic analyses of 'Higher Hamamelididae' based on plastid sequence data. Am. J. Bot. 84, 1407-1419.

Mast, A.R., Givnish, T.J., 2002. Historical biogeography and the origin of stomatal distributions in Banksia and Dryandra (Proteaceae) based on their cpDNA phylogeny. Am. J. Bot. 89, 13111323.

Matos, J.A., Schaal, B.A., 2000. Chloroplast evolution in the Pinus montezumae complex: a coalescent approach to hybridization. Evolution 54, 1218-1233.

McKinnon, G.E., Vaillancourt, R.E., Jackson, H.D., Potts, B.M., 2001. Chloroplast sharing in the Tasmanian eucalypts. Evolution 55, 703-711.

Mildenhall, D.C., 1980. New Zealand late Cretaceous and Cenozoic plant biogeography: a contribution. Palaeogeography, Palaeoclimatology, Palaeoecology 31, 197-233.

Mort, M.E., Soltis, P.S., Soltis, D.E., Mabry, M.L., 2000. Comparison of three methods for estimating internal support on phylogenetic trees. Syst. Biol. 49, 160-171.

Neuhaus, H., Link, G., 1987. The chloroplast trnAtys(UUU) gene from mustard (Sinapsis alba) contains a class II intron potentially coding for a maturase-related polypeptide. Curr. Genet. 11, 251257.

Olmstead, R.G., Palmer, J.D., 1994. Chloroplast DNA systematics: a review of methods and data analysis. Am. J. Bot. 81, 1205-1224.

Poisson, J., 1874. Recherches sur les Casuarina et en particulier sur ceux de la Nouvelle-Calédonie. Nouvelle Archives du Muséum d'Histoire Naturelle 10, 59-111.

Posada, D., Crandall, K.A., 1998. Modeltest: testing the model of DNA substitution. Bioinformatics 14, 817-818.

Qiu, Y.L., Chase, M.W., Hoot, S.B., Conti, E., Crane, P.R., Sytsma, K.J., Parks, C.R., 1998. Phylogenetics of the Hamamelidae and their allies: parsimony analyses of nucleotide sequenes of the plastid gene $r b c$ L. Int. J. Plant Sci. 159, 891-905.

Scriven, L.J., Hill, R.S., 1995. Macrofossil Casuarinaceae: their identification and the oldest macrofossil record, Gymnostoma antiquum sp. nov., from the Late Paleocene of New South Wales, Australia. Aust. Syst. Bot. 8, 1035-1053.
Setoguchi, H., Osawa, T.A., Pintaud, J.-C., Jaffré, T., Veillon, J.-M., 1998. Phylogenetic relationships within Araucariaceae based on $r b c \mathrm{~L}$ gene sequences. Am. J. Bot. 85, 1507-1516.

Sogo, A., Setoguchi, H., Noguchi, J., Jaffré, T., Tobe, H., 2001. Molecular phylogeny of Casuarinaceae based on $r b c \mathrm{~L}$ and $m a t \mathrm{~K}$ gene sequences. J. Plant Res. 114, 259-464.

Specht, C.D., Kress, W.J., Stevenson, D.W., DeSalle, R., 2001. A molecular phylogeny of Costaceae (Zingiberales). Mol. Phylogenet. Evol. 21, 333-345.

Steane, D.A., Byrne, M., Vaillancourt, R.E., Potts, B.M., 1998. Chloroplast DNA polymorphism signals complex interspecific interactions in Eucalyptus (Myrtaceae). Aust. Syst. Bot. 11, 2540.

Steane, D.A., Scotland, R.W., Mabberley, D.J., Olmstead, R.G., 1999. Molecular systematics of Clerodendrum (Lamiaceae): ITS sequences and total evidence. Am. J. Bot. 86, 98-107.

Steane, D.A., Nicolle, D., McKinnon, G.E., Vaillancourt, R.E., Potts, B.M., 2002. Higher level relationships among the eucalypts are resolved by ITS-sequence data. Aust. Syst. Bot. 15, 49-62.

Steele, K.P., Vilgalys, R., 1994. Phylogenetic analyses of Polemoniaceae using nucleotide sequences of the plastid gene matK. Syst. Bot. $19,126-142$.

Sugita, M., Shinozaki, K., Sugiura, M., 1985. Tobacco chloroplast tRNA ${ }^{\text {Lys }}$ (UUU) gene contains a 2.5-kilobase-pair intron: an open reading frame and a conserved boundary sequence in the intron. Proc. Natl. Acad. Sci. USA 82, 3557-3561.

Swenson, U., Backlund, A., McLoughlin, S., Hill, R.S., 2001. Nothofagus biogeography revisited with special emphasis on the enigmatic distribution of subgenus Brassospora in New Caledonia. Cladistics 17, 28-47.

Swofford, D.L., 1999. PAUP*. Phylogenetic analysis using parsimony (* and other methods), Version 4. Sinauer, Sunderland, Massachusetts, USA.

Thomson, J.S., 2002. An improved non-cryogenic transport and storage preservative facilitating DNA extraction from "difficult" plants collected at remote sites. Telopea 9, 755-760.

Torrey, J.G., 1983. Root development and root nodulation in Casuarina. In: Midgley, S.J., Turnbull, J.W., Johnston, R.D. (Eds.), Casuarina ecology, management and utilization: proceedings of an International Workshop, Canberra, Austraila, 17-21 August 1981. CSIRO, Australia, pp. 180-192.

Turnbull, J.W., Martensz, P.N., 1983. Seed production, collection and germination in Casuarinaceae. In: Midgley, S.J., Turnbull, J.W., Johnston, R.D. (Eds.), Casuarina ecology, management and utilization: proceedings of an International Workshop, Canberra, Austraila, 17-21 August 1981. CSIRO, Australia, pp. 126-132.

Wilson, K.L., Johnson, L.A.S., 1989. Casuarinaceae. Flora of Australia 3, 100-174.

Winkworth, R.C., Wagstaff, S.J., Glenny, D., Lockhart, P.J., 2002. Plant dispersal N.E.W.S. from New Zealand. Trends Ecol. Evol. 17, 514-520.

Wright, S.D., Yong, C.G., Dawson, J.W., Whittaker, D.J., Gardner, R.C., 2000. Riding the ice age El Niño? Pacific biogeography and evolution of Metrosideros subg Metrosideros (Myrtaceae) inferred from nuclear ribosomal DNA. Proc. Natl. Acad. Sci. USA 97, 4118-4123.

Wright, S.D., Yong, C.G., Wichman, S.R., Dawson, J.W., Gardner, R.C., 2001. Stepping stones to Hawaii: a trans-equatorial dispersal pathway for Metrosideros (Myrtaceae) inferred from nrDNA (ITS + ETS). J. Biogeogr. 28, 769-774. 